\title{
Relationship between Teachers' Content Knowledge, Qualifications, Experience and Students' Achievement in Chemistry
}

\author{
Oluwatosin Victor Ajayi \\ Department of Curriculum and Teaching, Benue State University, PMB 102119, Makurdi, Nigeria \\ Email: drvictorajayi@gmail.com \\ Accepted 7 May, 2017
}

\begin{abstract}
The study investigated the relationship between teachers' content knowledge, qualifications, experience and students' achievement in Chemistry in Otukpo Local Government Area (LGA) of Benue State, Nigeria. The study was guided by two research questions and two hypotheses. A sample of 25 Chemistry teachers and 187 Chemistry students out of a population of 98 Chemistry teachers and 2,897 SSII students respectively from Otukpo LGA of Benue State, Nigeria was used for the study. A validated 50 item Chemistry Teachers' Content Knowledge Achievement Test (CTCKAT) and 25 item Chemistry Students' Achievement Test (CSAT) was the instruments used to collect data. Reliability coefficient of 0.78 was established using Pearson Product Correlation. The study adopted an ex-post facto research design. Frequencies, and Percentages were used to answer the research questions and Pearson Correlation Moment Coefficient was used to test the hypotheses. The result indicated among others that there is a strong positive correlation between teachers' content knowledge scores in Chemistry with students' achievement scores in Chemistry $(r=0.89)$, the result also revealed that, there is a strong positive correlation between teachers' qualifications and students' achievement scores ( $r=0.72$ ), and also there is a positive correlation between teachers' years of teaching experience and students' achievement $(r=0.51)$. The study recommended among others that students' achievement in Chemistry is likely to improve in Otukpo Local Government Area of Benue State, if teachers engaged to teach chemistry have good content knowledge of Chemistry and good teaching qualifications.
\end{abstract}

Key words: Teachers' content knowledge, qualifications, experience, achievement, chemistry.

\section{INTRODUCTION}

Science and technology have always been recognized as critical factors in the process of every nation's development. Through the applications of science and technology, the resources of nations have been transformed into goods and services all over the world (Agommuoh and Nzewi, 2008). The valuable role science play in the development of a nation cannot be overemphasized. Chemistry as a core science subject is linked to everything on earth as aptly captured in a slogan, "what on earth is not chemistry?" chemistry plays a pivotal role at engineering sustainable economic development and growth in any nation. Put succinctly there is no aspect of human endeavor or natural phenomena that chemistry does not feature. It features prominently in the areas of oil and gas, agriculture, health, environment, solid minerals, textile, cosmetics, water supply and sanitation, crime detection, pulp and paper, waste management just to name a few. Chemistry is the catalyst of sustainable national growth and development. The knowledge of chemistry has a wide application in areas such as manufacturing/production of fertilizers, herbicides/pesticides, production and refining of crude oil, manufacturing of drug in medicine, in aviation industry and other industrial processes (Ajayi, 2016).

Despite the important of chemistry, the high rates of failure recorded by students in private and public schools and colleges in Nigeria have been a major concern to 
researchers. Consequently, the low achievement in chemistry external examinations such as Senior Secondary Certificate Examination conducted West Africa Examination Council and National Examination Council had been traced to some teachers' characteristics such as teachers' content knowledge, teachers' qualifications workload, experience, age, income, self-motivation and attitude and so on. Many studies attest that some teachers contribute more to their students' academic growth than other teachers. Teachers have been shown to have an important influence on students' academic achievement and they also play a crucial role in educational attainment because the teacher is ultimately responsible for translating policy into action and principles based on practice during interaction with the students (Agharuwhe and Nkechi, 2009). Both teaching and learning depends on teachers: no wonder a teacher with a good content knowledge has been conceptualized as one who produces desired results in the course of his duty as a teacher (Ajayi, 2014). In other words the content knowledge of teacher in classroom interaction with the students could be responsible for the observed poor achievement of students in chemistry. In recent years, teachers' knowledge of the subject matter they teach has attracted increasing attention from policymakers.

Researchers have typically measured teachers' knowledge using proxy variables, such as courses taken, degrees attained, or results from basic skills tests. However a lot of factors may hinder effective dissemination of knowledge to the understanding of the content to the students, such factors may be teachers' content knowledge, teachers' qualification, experience, workload, classroom practices among others. Content Knowledge encompasses conceptual and procedural knowledge and understanding of the nature and structure of the subject (Grossman, 2012). Conceptual knowledge is knowledge of facts, principles and theories. Content knowledge is the amount of information and understanding that the teachers have on a subject matter. In this study, teachers' content knowledge (TCK) refers to the teachers' knowledge of various aspects of chemistry such as organic chemistry, inorganic chemistry, physical chemistry and analytical chemistry and the procedural knowledge of solving mathematical related chemistry problems (Ajayi, 2016). Teaching and learning of chemistry depends to a large extent on teachers' own knowledge of the content and ability to adequately deliver the instruction to the students.

A teacher's qualification showed the educational attainments of the teacher. Many studies have examined which qualification of teachers positively related to students achievement. Teachers' having a higher qualification or have an advanced degree in their teaching subject has a positive effect on student achievement (Syed, 2013; Athar, 2016). Some studies found that teachers' educational qualification significantly relationship with students' achievement in chemistry (Ugbe and Agim, 2012; Asikhia, 2014; Olaleye, 2015). While some studies also found that educational qualification have no significant relationship with students' achievement in chemistry (Adaramola, 2010; Raji 2011). Studies on teachers' qualification in chemistry continued to yield inconsistence. Therefore, it is of interest to find out if there is a relationship between teachers' qualification and students' achievement in chemistry.

Teachers' experience level (experienced or less experienced) could influence his effectiveness and consequently the students' achievement. In this study, the ranges are between 0-5 years, 6-10 years and 11 and above years. The first range is less experienced while the second range and third range is experienced. Experienced teachers have amassed years of service and a repertoire of classroom skills and strategies. Ayuba (2014) concluded in his study that teachers' with five or more than five years of teaching experience were proved effective in teaching while less experienced proved to have a negative effect on student achievement. While some studies revealed that teachers' year of teaching experience have no relationship with students' achievement (Adewale, 2014; Alake, 2015). It therefore means that there must be an underlying force which is responsible for this trend of poor students' achievement in Chemistry. Against this backdrop, the present study examined the relationship between teachers' content knowledge, teachers' qualification, teachers' years of experience and students' achievement in chemistry in Otukpo Local Government Area of Benue State.

\section{Research Questions}

The following research questions were answered in this study:

1. What is the relationship between teachers' content knowledge of chemistry and students' achievement in Chemistry?

2. What is the relationship between chemistry teachers' qualifications and students' achievement in Chemistry?

3. What is the relationship between chemistry teachers' experience and students' achievement in Chemistry?

\section{Hypotheses}

The following null hypotheses were tested at 0.05 level of significance:

1. There is no significant relationship between teachers' content knowledge of chemistry and students' 
achievement in Chemistry.

2. There is no significant relationship between chemistry teachers' qualifications and students' achievement in Chemistry.

3. There is no significant relationship between chemistry teachers' experience and students' achievement in Chemistry.

\section{METHODOLOGY}

Chemistry Teachers' Content Knowledge Achievement Test (CTCKAT) and Chemistry Students' Achievement Test (CSAT) were used for data collection. The study employed causal comparative or ex -post facto survey research design where the variables were correlated to determine the degree of relationship between the independent variables (teachers' content knowledge, teachers qualifications, years of experience) and the dependent variable (students' achievement) in Chemistry. CTCKAT and CSAT were face and content validated by three experts in Chemistry education/Measurement and Evaluation from Benue State University, Makurdi. Firstly, the correlation coefficient value for teachers' content knowledge and students' achievement in chemistry was 0.40 . Secondly, the correlation coefficient value for teachers' qualification and students' achievement was 0.43. Thirdly, the correlation coefficient value for teachers' experience and students' achievement was 0.41 . The value were considered valid for this study, based on the fact, that the calculated correlation coefficients value can be considered low enough to be used for this study

The researcher visited all the schools selected for the study and administered copies of the 50 items CTCKAT to the Chemistry Teachers in each of the sampled schools. The researcher solicited for respondents (Chemistry teachers) cooperation in answering the achievement test within two hour after given the test to them. The researcher closely monitors the respondents in providing answers to the required questions in the CTCKAT. All the distributed and answered copies of the achievement test were collected instantly from the respondents and the exercise lasted for two weeks. The researcher also used the regular chemistry teachers of each of the sampled schools as research assistants to administer the CSAT to the students inform of regular classroom test. The researcher also monitored the research assistants on the conduct of the achievement test to ensure uniformity of the instrument and the exercise also lasted for three weeks.

\section{Results and Table}

Presentations in this section are based on research questions and hypotheses:

\section{Research Question One}

Table 1 presents the frequencies and percentages of categories of teachers' content knowledge scores in chemistry and students' scores in chemistry and Pearson correlation coefficient $(r)$. Note that category C, B and A represent the scores of teachers between the ranges of 50-below, 51-70, 71-100 respectively. The table 1 revealed that $67(35.8 \%), 7(3.7 \%)$ and $0(0 \%)$ of students that scores between the range of 28.00 to 44.00 were taught by category $\mathrm{C}$, category $\mathrm{B}$ and category $\mathrm{A}$ chemistry teachers respectively. $0(0 \%), 42(22.5 \%)$ and $17(9.1 \%)$ of students that scores between the range of 50.00 to 70.00 were taught by category C, category B and category A chemistry teachers respectively while $0(0 \%), 0(0 \%)$ and $54(28.9 \%)$ of students that scores between the range of 78.00 to 94.00 were taught by category C, category B and category A chemistry teachers' respectively.

\section{Research Question Two}

Table 2 presents the frequencies and percentages of scores of teachers' qualifications in chemistry and students' scores in chemistry and Pearson correlation coefficient $(r)$. Table 2 reveals 69(36.9\%), 13(7.0\%) and $0(0 \%)$ of students that scores between the range of 28.00 to 50.00 were taught by chemistry teachers' with NCE, B.Sc without PGDE and B.Sc.Ed respectively while $37(19.8 \%), 48(25.6 \%)$ and $8(4.3 \%)$ of students that scores between the range of 60.00 to 80.00 were taught by chemistry teachers with NCE, B.Sc without PGDE and B.Sc.Ed respectively. Table 2 also revealed that $0(0.0 \%)$, $0(0.0 \%)$ and $12(6.4 \%)$ of students that scores between the range of 84.00 to 94.00 were taught by chemistry teachers with NCE, B.Sc without PGDE and B.Sc.Ed respectively.

\section{Research Question Three}

Table 3 presents the frequencies and percentages of scores in teachers' teaching experience and students' scores in chemistry. The table reveals $71(38.0 \%)$, $11(5.9 \%)$ and $0(0 \%)$ of students that scores between the range of 28.00 to 50.00 were taught by chemistry teachers with 1-5 years, 6-10 years and 11-Above years of teaching experience respectively while $7(3.7 \%)$, $52(27.8 \%)$ and $46(24.6 \%)$ of students that scores between the range of 60.00 to 94.00 were taught by chemistry teachers with 1-5 years, 6-10 years and 11Above years of teaching experience respectively.

\section{Hypothesis One}

The result in table 4 reveals $r=0.89, p=0.00$. This implies that the null hypothesis that says, there is no significant 
Table 1: Frequencies, and Percentages of Teacher Content Knowledge and Students' Achievement in Chemistry

\begin{tabular}{|c|c|c|c|c|c|}
\hline \multicolumn{2}{|c|}{ Students' Achievement in Chemistry } & \multicolumn{4}{|c|}{ Categories of Teachers' Content Knowledge } \\
\hline & & Category & Category & Category & Total \\
\hline & & c & B & A & \\
\hline 28.00 & Count & 6 & 0 & 0 & 6 \\
\hline & $\%$ of Total & $3.2 \%$ & $0.0 \%$ & $0.0 \%$ & $3.2 \%$ \\
\hline 32.00 & Count & 8 & 0 & 0 & 8 \\
\hline & $\%$ of Total & $4.3 \%$ & $0.0 \%$ & $0.0 \%$ & $4.3 \%$ \\
\hline 36.00 & Count & 8 & 0 & 0 & 8 \\
\hline & $\%$ of Total & $4.3 \%$ & $0.0 \%$ & $0.0 \%$ & $4.3 \%$ \\
\hline 38.00 & Count & 8 & 0 & 0 & 8 \\
\hline & $\%$ of Total & $4.3 \%$ & $0.0 \%$ & $0.0 \%$ & $4.3 \%$ \\
\hline 40.00 & Count & 9 & 0 & 0 & 9 \\
\hline & $\%$ of Total & $4.8 \%$ & $0.0 \%$ & $0.0 \%$ & $4.8 \%$ \\
\hline 42.00 & Count & 12 & 2 & 0 & 14 \\
\hline & $\%$ of Total & $6.4 \%$ & $1.1 \%$ & $0.0 \%$ & $7.5 \%$ \\
\hline 44.00 & Count & 16 & 5 & 0 & 21 \\
\hline & $\%$ of Total & $8.6 \%$ & $2.6 \%$ & $0.0 \%$ & $11.2 \%$ \\
\hline 50.00 & Count & 0 & 8 & 0 & 8 \\
\hline & $\%$ of Total & $0.0 \%$ & $4.3 \%$ & $0.0 \%$ & $4.3 \%$ \\
\hline 60.00 & Count & 0 & 8 & 0 & 8 \\
\hline & $\%$ of Total & $0.0 \%$ & $4.3 \%$ & $0.0 \%$ & $4.3 \%$ \\
\hline 64.00 & Count & 0 & 15 & 0 & 15 \\
\hline & $\%$ of Total & $0.0 \%$ & $8.0 \%$ & $0.0 \%$ & $8.0 \%$ \\
\hline 70.00 & Count & 0 & 11 & 17 & 28 \\
\hline & $\%$ of Total & $0.0 \%$ & $5.9 \%$ & $9.0 \%$ & $14.9 \%$ \\
\hline 78.00 & Count & 0 & 0 & 7 & 7 \\
\hline & $\%$ of Total & $0.0 \%$ & $0.0 \%$ & $3.7 \%$ & $3.7 \%$ \\
\hline 80.00 & Count & 0 & 0 & 16 & 16 \\
\hline & $\%$ of Total & $0.0 \%$ & $0.0 \%$ & $8.6 \%$ & 8.6 \\
\hline 84.00 & Count & 0 & 0 & 7 & 7 \\
\hline & $\%$ of Total & $0.0 \%$ & $0.0 \%$ & $3.7 \%$ & $3.7 \%$ \\
\hline 88.00 & Count & 0 & 0 & 8 & 8 \\
\hline & $\%$ of Total & $0.0 \%$ & $0.0 \%$ & $4.3 \%$ & $4.3 \%$ \\
\hline 92.00 & Count & 0 & 0 & 8 & 8 \\
\hline & $\%$ of Total & $0.0 \%$ & $0.0 \%$ & $4.3 \%$ & $4.3 \%$ \\
\hline 94.00 & Count & 0 & 0 & 8 & 8 \\
\hline & $\%$ of Total & $0.0 \%$ & $0.0 \%$ & $4.3 \%$ & $4.3 \%$ \\
\hline Total & Count & 67 & 49 & 71 & 187 \\
\hline & $\%$ of Total & $35.8 \%$ & $26.2 \%$ & $38.0 \%$ & $100 \%$ \\
\hline
\end{tabular}

Table 2: Frequencies and Percentages of Teachers' Qualification and Students' Achievement in Chemistry

\begin{tabular}{llcccc}
\hline Students' Achievement in & Chemistry & NCE & $\begin{array}{c}\text { Teachers' Qualifications } \\
\text { B.Sc } \\
\text { B.Sc.Ed }\end{array}$ & Total \\
& & & without PGDE & \\
\hline 28.00 & Count & 6 & 0 & 0 & 6 \\
& $\%$ of Total & $3.2 \%$ & $0.0 \%$ & $0.0 \%$ & $3.2 \%$ \\
32.00 & Count & 8 & 2 & 0 & 10 \\
& $\%$ of Total & $4.3 \%$ & $1.1 \%$ & $0.0 \%$ & $5.3 \%$ \\
36.00 & Count & 8 & 2 & 0 & 10 \\
& $\%$ of Total & $4.3 \%$ & $1.1 \%$ & $0.0 \%$ & $5.3 \%$ \\
38.00 & Count & 8 & 2 & 0 & 10 \\
& \% of Total & $4.3 \%$ & $1.1 \%$ & $0.0 \%$ & $5.3 \%$ \\
40.00 & Count & 9 & 0 & 0 & 9 \\
& \% of Total & $4.8 \%$ & $0.0 \%$ & $0.0 \%$ & $4.8 \%$ \\
\hline
\end{tabular}


Table 2. Contd.

\begin{tabular}{|c|c|c|c|c|c|}
\hline \multirow[t]{2}{*}{42.00} & Count & 10 & 2 & 0 & 12 \\
\hline & $\%$ of Total & $5.3 \%$ & $1.1 \%$ & $0.0 \%$ & $6.4 \%$ \\
\hline \multirow[t]{2}{*}{44.00} & Count & 18 & 3 & 0 & 21 \\
\hline & $\%$ of Total & $9.6 \%$ & $1.6 \%$ & $0.0 \%$ & $11.2 \%$ \\
\hline \multirow[t]{2}{*}{50.00} & Count & 2 & 2 & 0 & 4 \\
\hline & $\%$ of Total & $1.1 \%$ & $1.1 \%$ & $0.0 \%$ & $2.2 \%$ \\
\hline \multirow[t]{2}{*}{60.00} & Count & 7 & 6 & 2 & 8 \\
\hline & $\%$ of Total & $3.7 \%$ & $3.2 \%$ & $1.1 \%$ & $4.3 \%$ \\
\hline \multirow[t]{2}{*}{64.00} & Count & 8 & 13 & 1 & 15 \\
\hline & $\%$ of Total & $4.3 \%$ & $7.0 \%$ & $0.5 \%$ & $8.0 \%$ \\
\hline \multirow[t]{2}{*}{70.00} & Count & 9 & 12 & 1 & 28 \\
\hline & $\%$ of Total & $4.8 \%$ & $6.4 \%$ & $0.5 \%$ & $14.9 \%$ \\
\hline \multirow[t]{2}{*}{78.00} & Count & 8 & 7 & 2 & 7 \\
\hline & $\%$ of Total & $4.3 \%$ & $3.7 \%$ & $1.1 \%$ & $3.7 \%$ \\
\hline \multirow[t]{2}{*}{80.00} & Count & 5 & 10 & 2 & 16 \\
\hline & $\%$ of Total & $2.7 \%$ & $5.3 \%$ & $1.1 \%$ & 8.6 \\
\hline \multirow[t]{2}{*}{84.00} & Count & 0 & 0 & 3 & 3 \\
\hline & $\%$ of Total & $0.0 \%$ & $0.0 \%$ & $1.6 \%$ & $1.6 \%$ \\
\hline \multirow[t]{2}{*}{88.00} & Count & 0 & 0 & 2 & 2 \\
\hline & $\%$ of Total & $0.0 \%$ & $0.0 \%$ & $1.1 \%$ & $1.1 \%$ \\
\hline \multirow[t]{2}{*}{92.00} & Count & 0 & 0 & 2 & 2 \\
\hline & $\%$ of Total & $0.0 \%$ & $0.0 \%$ & $1.1 \%$ & $1.1 \%$ \\
\hline \multirow[t]{2}{*}{94.00} & Count & 0 & 0 & 5 & 5 \\
\hline & $\%$ of Total & $0.0 \%$ & $0.0 \%$ & $2.7 \%$ & $2.7 \%$ \\
\hline \multirow[t]{2}{*}{ Total } & Count & 106 & 61 & 20 & 187 \\
\hline & $\%$ of Total & $56.7 \%$ & $32.6 \%$ & $10.7 \%$ & $100 \%$ \\
\hline
\end{tabular}

Table 3: Frequencies and Percentages of Teachers' Teaching Experience and Students' Achievement in Chemistry

\begin{tabular}{|c|c|c|c|c|c|}
\hline \multirow{2}{*}{\multicolumn{2}{|c|}{$\begin{array}{l}\text { Students' Understanding of } \\
\text { Civic Rights and Responsibilities }\end{array}$}} & \multicolumn{4}{|c|}{ Teachers' Years of Teaching Experience } \\
\hline & & 1-5 Years & 6-10 Years & 11-Above & Total \\
\hline \multirow[t]{2}{*}{28.00} & Count & 6 & 0 & 0 & 6 \\
\hline & $\%$ of Total & $3.2 \%$ & $0.0 \%$ & $0.0 \%$ & $3.2 \%$ \\
\hline \multirow{2}{*}{32.00} & Count & 8 & 0 & 0 & 8 \\
\hline & $\%$ of Total & $4.3 \%$ & $0.0 \%$ & $0.0 \%$ & $4.3 \%$ \\
\hline \multirow[t]{2}{*}{36.00} & Count & 8 & 0 & 0 & 8 \\
\hline & $\%$ of Total & $4.3 \%$ & $0.0 \%$ & $0.0 \%$ & $4.3 \%$ \\
\hline \multirow[t]{2}{*}{38.00} & Count & 8 & 0 & 0 & 8 \\
\hline & $\%$ of Total & $4.3 \%$ & $0.0 \%$ & $0.0 \%$ & $4.3 \%$ \\
\hline \multirow[t]{2}{*}{40.00} & Count & 9 & 0 & 0 & 9 \\
\hline & $\%$ of Total & $4.8 \%$ & $0.0 \%$ & $0.0 \%$ & $4.8 \%$ \\
\hline \multirow[t]{2}{*}{42.00} & Count & 11 & 3 & 0 & 14 \\
\hline & $\%$ of Total & $5.9 \%$ & $1.6 \%$ & $0.0 \%$ & $7.5 \%$ \\
\hline 44.00 & Count & $\begin{array}{c}16 \\
85 \%\end{array}$ & $\begin{array}{l}5 \\
27 \%\end{array}$ & $\begin{array}{c}0 \\
0\end{array}$ & 21 \\
\hline \multirow{2}{*}{50.00} & Count & $\begin{array}{l}0.5 \% \\
5\end{array}$ & 3 & 0 & 8 \\
\hline & $\%$ of Total & $2.7 \%$ & $1.6 \%$ & $0.0 \%$ & $4.3 \%$ \\
\hline \multirow[t]{2}{*}{60.00} & Count & 0 & 8 & 0 & 8 \\
\hline & $\%$ of Total & $0.0 \%$ & $4.3 \%$ & $0.0 \%$ & $4.3 \%$ \\
\hline \multirow[t]{2}{*}{64.00} & Count & 0 & 8 & 7 & 15 \\
\hline & $\%$ of Total & $0.0 \%$ & $4.3 \%$ & $3.7 \%$ & $8.0 \%$ \\
\hline \multirow[t]{2}{*}{70.00} & Count & 4 & 21 & 3 & 28 \\
\hline & $\%$ of Total & $2.1 \%$ & $11.2 \%$ & $1.6 \%$ & $14.9 \%$ \\
\hline \multirow[t]{2}{*}{78.00} & Count & 0 & 7 & 0 & 7 \\
\hline & $\%$ of Total & $0.0 \%$ & $3.7 \%$ & $0.0 \%$ & $3.7 \%$ \\
\hline
\end{tabular}


Table 3. Contd.

\begin{tabular}{llcccc}
\hline 80.00 & Count & 3 & 2 & 11 & 16 \\
& $\%$ of Total & $1.6 \%$ & $2.1 \%$ & $5.9 \%$ & 8.6 \\
84.00 & Count & 0 & 3 & 4 & 7 \\
& $\%$ of Total & $0.0 \%$ & $1.6 \%$ & $2.1 \%$ & $3.7 \%$ \\
88.00 & Count & 0 & 3 & 5 & 8 \\
& \% of Total & $0.0 \%$ & $1.6 \%$ & $2.7 \%$ & $4.3 \%$ \\
92.00 & Count & 0 & 0 & 8 & 8 \\
& \% of Total & $0.0 \%$ & $0.0 \%$ & $4.3 \%$ & $4.3 \%$ \\
94.00 & Count & 0 & 0 & 8 & 8 \\
& \% of Total & $0.0 \%$ & $0.0 \%$ & $4.3 \%$ & $4.3 \%$ \\
Total & Count & $\mathbf{7 8}$ & $\mathbf{6 3}$ & $\mathbf{4 6}$ & $\mathbf{1 8 7}$ \\
& \% of Total & $\mathbf{4 1 . 7 \%}$ & $\mathbf{3 3 . 7} \%$ & $\mathbf{2 4 . 6 \%}$ & $\mathbf{1 0 0 \%}$ \\
\hline
\end{tabular}

Table 4: Correlation of Teachers' Content knowledge and Students' Achievement in Chemistry

\begin{tabular}{lcccc}
\hline Variables & N & r & P Value & Decision \\
\hline Teachers' Content Knowledge & 25 & $0.890^{*}$ & 0.000 & $\mathrm{~S}$ \\
and Students' Achievement & 187 & & & \\
\hline
\end{tabular}

*Significant at $\mathrm{P}<0.05$

$S=$ Significant, NS= Not Significant.

Table 5: Correlation of Teachers' Qualifications and Students' Achievement in Chemistry

\begin{tabular}{llccc}
\hline Variables & $\mathbf{N}$ & $\mathbf{r}$ & P Value & Decision \\
\hline Teachers' Qualification and & 25 & $0.721^{*}$ & 0.000 & $\mathrm{~S}$ \\
Students' Achievement & 187 & & & \\
\hline
\end{tabular}

*Significant at $\mathrm{P}<0.05$

$\mathrm{S}=$ Significant, NS= Not Significant.

Table 6: Correlation of Teachers' Years of Teaching Experience and Students' Achievement in Chemistry

\begin{tabular}{|c|c|c|c|c|}
\hline Variables & $\mathbf{N}$ & $r$ & P Value & Decision \\
\hline $\begin{array}{l}\text { Teachers' Experience and } \\
\text { Students' Achievement }\end{array}$ & $\begin{array}{c}25 \\
187\end{array}$ & $0.512^{*}$ & 0.000 & $\mathrm{~S}$ \\
\hline
\end{tabular}

relationship between teachers' content knowledge and students' achievement in chemistry is not accepted. The conclusion drawn was that chemistry teachers' content knowledge had a strong positive correlation with students' achievement in chemistry. That is, $79.21 \%\left(0.890^{2}\right)$ of the variation in students' achievement in chemistry is explained by teachers' content knowledge.

\section{Hypothesis Two}

The result in table 5 reveals $r=0.72, p=0.00$. This implies that the null hypothesis that says, there is no significant relationship between chemistry teachers' qualification and students' achievement in chemistry is not accepted. The conclusion drawn was that chemistry teachers' qualifications had a strong positive correlation with students' achievement in chemistry. That is, $51.98 \%$ $\left(0.721^{2}\right)$ of the variation in students' achievement in chemistry is explained by teachers' qualifications.

\section{Hypothesis Three}

Table 6 presents the correlation of chemistry teachers' years of teaching experience and students' achievement in chemistry. The table reveals $r=0.51, p=0.00$. This implies that the null hypothesis of no significant not 
relationship between chemistry teachers' teaching experience and students' achievement in chemistry is accepted. It was concluded that chemistry teachers' years of teaching experience had an average positive correlation with students' achievement. That is, $26 \%$ $\left(0.512^{2}\right)$ of the variation in students' achievement in chemistry is explained by teachers' years of teaching experience.

\section{DISCUSSION}

The finding revealed that chemistry teachers' content knowledge had a strong positive correlation with students' achievement in chemistry. This is in line with Olaleye (2015) who concluded that teachers' content knowledge of history significantly predicted their performance in history. The Pearson correlation coefficient between the scores in teachers' qualification and students' achievement was 0.72 . This indicates that there is a strong positive relationship between teachers' qualifications and students' achievement in chemistry. This is in line with Abe (2014) who confirmed that teachers' qualifications significantly predicted students' performance in mathematics and against the finding of Solomon (2013) who concluded that teachers qualifications has no significant effect on students' achievement in physical health education. The finding also shows a positive relationship between years of teaching experience of chemistry teachers' and students' achievement. This implies that chemistry teachers' years of teaching experience had significant effect on students' achievement in chemistry. This is in line with Adebanjo (2015) who concluded that teaching experience of physic teachers' had significant effect on students' cognitive achievement in physic.

\section{CONCLUSION AND RECOMMENDATIONS}

Based on the findings of this study it was concluded that the content knowledge of teachers, teachers' qualifications and years of experiences have significant relationship with students' achievement in Chemistry in Otukpo Local Government Area of Benue State, Nigeria. Based on the conclusion, the following recommendations were made;

i. Students' achievement in chemistry is likely to improve, if teachers engaged to teach have good content knowledge of Chemistry.

ii. Students' achievement in chemistry is likely to improve, if qualified chemistry teachers with good teaching qualifications (B.Sc.Ed or B.Sc with PGDE degree) in chemistry are employed to teach chemistry. iii Teachers with NCE should strive to improve their knowledge in chemistry by acquiring additional qualification through in-service training or part- time or sandwich degree programme in the Universities around them.

iv Graduate teachers without teaching qualification should endeavour to proceed on PGDE or PDE programme to enhance their teaching method in Chemistry.

$\checkmark$ Experienced chemistry teachers should be encouraged to let their wealth of experience bear on the teaching and learning of chemistry to improve students' achievement.

\section{REFERENCES}

Abe, T.O. (2014). The effect of teachers' qualifications on students' performance in mathematics. Sky J. Educ. Res. 2(1): 010-014

Adebanjo, H.A. (2015). Relationship between teachers teaching experience and students' cognitive achievement in physic. J. Educ. Theory. 3(2): 34-40

Adaramola, S.S. (2010). Relationship between teachers' qualification and students' academic performance in Basic Science in Akure Local Government Area of Ondo State. Unpublished M.Ed Dissertation, Adekunle Ajasin University, Akoko, Ondo State.

Adewale, (2014). Impact of Teacher Knowledge of the Goals and Content of Integrated Science on Pupils Performance at the Primary School level in Makurdi LGA. Unpublished M.Ed Dissertation, Ekiti State University, Ado Ekiti.

Agharuwhe, A.A. and Nkechi, M.U. (2009). Teachers' Effectiveness and Students' Academic Performance in Public Secondary Schools in Delta State, Nigeria. Stud Home Comm Sci. 3(2),107-113.

Ajayi, O. V. (2016). Effect of hands -on activities on senior secondary chemistry students' achievement and retention in stoichiometry in Zone C of Benue State. Unpublished M.Ed dissertation, Benue State University, Makurdi.

Alake, H. B. (2015). Influence of teachers' experience and age on student achievement in Basic Science. J. Educ practices, 8(2), 23-29

Asikhia, A.D. (2014). Contribution of teachers' credentialing routes and experience levels on classroom management. Int. J. Instruction, 2(2):3-12.

Athar, (2016) Teacher Quality and Student Achievement: A Review of State Policy Evidence. Seattle W.A.; Center for the study of teaching and policy, University of Washinghton.

Ayuba, D. (2014). Examining Pedagogical Content Knowledge. Ibadan: Kunle Academic Publishers.

Grossman, S. (2012). Craft Knowledge and the Education of Teachers, in G. Grant (Ed) Review of Research in Education, 18(1), 59-74. Washington D.C.

Olaleye, A. (2015). Teacher qualification and students achievement in urban elementary schools. J. Urban Econ.. 66: 103-115.

Raji, F. (2011). Expanding teachers' knowledge base: A cognitive, psychological perspective on professional development, new paradigms and issues. New York: Teachers College Press.

Solomon, S.T. (2013). Relationship between teachers teaching experience and students performance in physical health education. $J$. Educ. Res. 2(3): 45-51

Syed, A. (2013). Teachers' Qualification as Predictors of Senior High School Students' Performance in Social Studies in the Central Region of Ghana. Unpublished PhD Thesis Central Region of Ghana University, Accra

Ugbe, A. M and Agim, J. A. (2012). Teacher qualification and students achievement in basic elementary science. J. Educ. Theory and Teaching. 6(2): 103-115. 